\title{
An intronic rare mutation in Presenilin-1 (PSEN-1) gene may be involved in the developement of Alzheimer's disease
}

\author{
Pranami Bhaumik*, Priyanka Ghosh, Subrata K. Dey \\ From International Conference on Human Genetics and 39th Annual Meeting of the Indian Society of \\ Human Genetics (ISHG) \\ Ahmadabad, India. 23-25 January 2013
}

\section{Background}

The Presenilin-1 gene (PSEN-1) encodes a protein component of gamma-secretase complex which is involved in processing of amyloid precursor protein (APP). The PSEN-1 is involved in many cardinal mechanisms in several molecular pathway which when impaired leads to the manifestation of Alzheimer's disease (AD). The aim of the study was to investigate the role of PSEN-1 gene in the developement of AD in Indian Bengali population.

\section{Materials and methods}

Blood samples were collected from $96 \mathrm{AD}$ patients and 173 age matched control individuals. DNA was isolated from each sample and then sequencing was performed for the exon 8 and its flanking introns of PSEN-1 gene.

\section{Results}

A rare mutation rs201992645 was identified within intron 8 and several in. silico analyses (Bioinformatic tools like 'Human Splicing Finder', 'SpliceAid' and 'mutation t@sting') revealed the mutation as 'potentially damaging' at the transcript splicing level. The genotypic frequencies of mutant heterozygotes were $0.031 \mathrm{AD}$, but it was not found in the control population.

\section{Conclusions}

We hypothesize that this rare mutation may be involved in the malfunctioning of Presenilin-1 protein and thus may play a role in the manifestation of Alzheimer's disease.

\footnotetext{
* Correspondence: pranami.bhaumik@gmail.com Human Genetics Research Laboratory, Department of Biotechnology and Biological Sciences, West Bengal University of Technology, Kolkata 700064, India
} and take full advantage of:

- Convenient online submission

- Thorough peer review

- No space constraints or color figure charges

- Immediate publication on acceptance

- Inclusion in PubMed, CAS, Scopus and Google Scholar

- Research which is freely available for redistribution

Submit your manuscript at Submit your manuscript at C BioMed Central 